\title{
Effects of luteinizing hormone on peroxisome proliferator- activated receptor $\gamma$ in the rat ovary before and after the gonadotropin surge
}

\author{
Jayeeta Banerjee and Carolyn M Komar \\ Department of Animal Science, lowa State University, 2356 Kildee Hall, Ames, Iowa 50011-3150, USA \\ Correspondence should be addressed to Carolyn M Komar; Email: ckomar@iastate.edu
}

\begin{abstract}
We have shown previously that mRNA for peroxisome proliferator-activated receptor $\gamma$ (PPAR $\gamma$ ) is expressed in granulosa cells and downregulated by the luteinizing hormone (LH) surge. The current studies were undertaken to test the hypothesis that LH stimulates a decrease in the expression of PPAR $\gamma$, as well as its activity, in granulosa cells. Ovaries were collected from immature rats 0 and $48 \mathrm{~h}$ after they received pregnant mares' serum gonadotropin (PMSG), and 4 and $24 \mathrm{~h}$ after administration of human chorionic gonadotropin (hCG), and used for protein isolation or processed for immunolocalization of PPAR $\gamma$. The amount of phosphorylated PPAR $\gamma$ was measured by immunoblot analysis to determine how LH affects the phosphorylation status, and therefore the activity, of PPAR $\gamma$. Granulosa cells were also collected from immature rats $48 \mathrm{~h}$ after PMSG. Cells were cultured with LH in the absence and presence of $\mathrm{H89}$ and cycloheximide to investigate the role of PKA and protein synthesis in the LH-mediated decline in mRNA for PPAR $\gamma$ respectively. Protein corresponding to PPAR $\gamma$ was localized to nuclei of granulosa cells 0 and $48 \mathrm{~h}$ after PMSG. Expression was greatly reduced by $4 \mathrm{~h}$ after hCG, with expression in mural granulosa cells lost before that in cumulus cells. The amount of phosphorylated PPAR $\gamma$ did not change during the periovulatory period. Blocking PKA activity had no effect on levels of mRNA for PPAR $\gamma$. However, levels of mRNA for PPAR $\gamma$ were significantly increased in cells treated with cycloheximide $(P<0.05$, ANOVA followed by Tukey's HSD $)$. These data suggest that PPAR $\gamma$ is tightly regulated in the ovary and that its expression is the primary mechanism by which LH influences the activity of PPAR $\gamma$. In addition, protein synthesis may be involved in modulating levels of PPAR $\gamma$ in granulosa cells.

Reproduction (2006) 131 93-101
\end{abstract}

\section{Introduction}

Peroxisome proliferator-activated receptor $\gamma(\operatorname{PPAR} \gamma)$ has been identified in ovarian tissue of man (Lambe \& Tugwood 1996), cattle (Sundvold et al. 1997, Löhrke et al. 1998), sheep (Froment et al. 2003), pigs (Schoppe et al. 2002), rats (Braissant et al. 1996, Komar et al. 2001) and mice (Cui et al. 2002). Mohan et al. (2002) reported that PPARy is also expressed in bovine oocytes. Our laboratory (Komar et al. 2001) and others (Löhrke et al. 1998, Mu et al. 2000, Schoppe et al. 2002, Veldhuis et al. 2002, Froment et al. 2003, Lovekamp-Swan et al. 2003) have shown that PPARy can also influence ovarian steroid production. Agonists of PPAR $\gamma$ have been reported to modify steroid production by both follicular (Komar et al. 2001, Schoppe et al. 2002, Veldhuis et al. 2002, Froment et al. 2003, LovekampSwan et al. 2003) and luteal cells (Löhrke et al. 1998, Mu et al. 2000).
PPAR $y$ is a member of the PPAR family of nuclear hormone receptors. This transcription factor is predominantly known for its role as an adipocyte differentiation factor (reviewed by Debril et al. 2001). PPARy also plays a role in lipid and glucose homeostasis, inflammation, the cell cycle, and cancer (reviewed by Escher \& Wahli 2000, Berger \& Moller 2002). It plays a critical role in placental development and function, as illustrated by disrupted trophoblast differentiation and placental vascularization in mice lacking PPAR y (Barak et al. 1999).

Aside from the roles mentioned above, there are several other mechanisms by which PPAR $y$ could affect ovarian function. PPARs can directly regulate the expression of the rate-limiting enzyme involved in prostaglandin production, cyclooxygenase-2 (COX-2) (Meade et al. 1999), and the proteolytic enzymes, MMP-3 (Yee et al. 1997) and MMP-9 (Marx et al. 1998, 1999, Shu et al. 2000). PPARy can also regulate the expression of vascular endothelial 
growth factor (Yamakawa et al. 2000), and could thereby affect angiogenesis, which is critical for follicular and luteal development. Genes involved with cell-cycle regulation (reviewed by Theocharis et al. 2004) and cell survival (Butts et al. 2004) are also regulated by PPAR $\gamma$.

There are various mechanisms regulating the activity of PPAR $\gamma$. PPAR $\gamma$ can be ubiquinated (Hauser et al. 2000), sumoylated (Ohshima et al. 2004) and nitrated (Shibuya et al. 2002), reducing its ability to affect gene transcription. The activity of PPAR $\gamma$ can also be modified by phosphorylation. The $A / B$ domain in the amino-terminus of this receptor contains mitogen-activated protein kinase sites at serines 84 (Adams et al. 1997) and 112 (Hu et al. 1996). Phosphorylation of PPARy decreases its activity (Hu et al. 1996, Adams et al. 1997, Reginato et al. 1998, Camp et al. 1999, Hsi et al. 2001), and increases its degradation by facilitating the targeting of PPAR $\gamma$ to the cellular ubiquitin-proteosome system (Floyd \& Stephens 2002).

Although a great deal has been learned about PPAR $\gamma$ since its discovery over a decade ago, not much is known about the role of PPAR $y$ in the ovary. Previous work from our laboratory has shown that mRNA for PPAR $\gamma$ is primarily localized in granulosa cells, and is downregulated in response to the luteinizing hormone (LH) surge (Komar et al. 2001). Interestingly, cells that responded to the LH surge lost expression of mRNA for PPAR $\gamma$, whereas those that did not respond to the surge maintained PPAR $\gamma$ expression (Komar \& Curry 2003).

The LH surge plays a pivotal role in the ovarian cycle. Genes essential for ovulation and luteinization are turned on by the LH surge (i.e., progesterone receptor) (Lydon et al. 1995), whereas genes not required for these processes, or that may interfere with ovulation or luteinization, are downregulated (i.e., cyclin D2) (Robker \& Richards 1998). One mechanism that may result in amplification of the effects of the $\mathrm{LH}$ surge on ovarian gene expression is regulation of PPAR $\gamma$, and therefore PPAR $\gamma$ regulated genes. Therefore, the following experiments were conducted to investigate the effects of the $\mathrm{LH}$ surge on the expression and activity of PPAR $y$ in the ovary. We tested the hypothesis that the $\mathrm{LH}$ surge stimulates a decrease in the amount of PPAR $\gamma$, as well as its activity, in periovulatory granulosa cells. Our findings show that the expression pattern of PPAR $y$ closely parallels that of its mRNA, and that protein synthesis may be involved in regulating the expression of PPAR $\gamma$.

\section{Materials and Methods}

\section{Materials}

Unless otherwise noted, all chemicals came from Sigma or Fisher Scientific (Pittsburgh, PA, USA). Antibodies against PPAR $\gamma$ were obtained from Santa Cruz Biotechnology (Santa Cruz, CA, USA). The antiphosphoserine antibody was purchased from Upstate (Lake Placid, NY, USA), and the antiactin antibody was obtained from Oncogene
Research Products (San Diego, CA, USA). Pregnant mares' serum gonadotropin (PMSG) and LH were purchased from the NIDDK's National Hormone and Peptide Program (Torrance, CA, USA). H89 was obtained from Alexis Biochemicals (San Diego, CA, USA).

\section{Animals}

All animal procedures were approved by lowa State University's Animal Care and Use Committee. Animals were housed in a controlled environment with a 14:10 light: dark cycle, and had free access to food and water. Female, Sprague-Dawley rats (Harlan Sprague-Dawley, Indianapolis, IN, USA) were injected with $10 I U$ PMSG subcutaneously on day 23 of age. Forty-eight hours later, animals received $10 \mathrm{IU}$ human chorionic gonadotropin (hCG) subcutaneously to stimulate ovulation and luteal development. Animals were killed and their ovaries collected 0 (no PMSG) and $48 \mathrm{~h}$ after receiving PMSG, and 4 and $24 \mathrm{~h}$ after hCG ( $n=4-5$ animals/time point). Ovaries were frozen and stored at $-70{ }^{\circ} \mathrm{C}$ until used for protein extraction, or fixed in $4 \%$ paraformaldehyde overnight at $4{ }^{\circ} \mathrm{C}$. Fixed tissues were embedded in paraffin for immunohistochemical analysis.

The role of protein kinase A (PKA) and protein synthesis in the LH-mediated decline in PPAR $\gamma$ was investigated with cultured granulosa cells collected from PMSG-primed animals. On day 23 of age, female rats received $10 \mathrm{IU}$ PMSG subcutaneously. After $48 \mathrm{~h}$, granulosa cells were collected as described previously (Mann et al. 1991).

\section{Immunohistochemistry}

PPAR $y$ was immunolocalized in fixed ovarian tissues collected from rats 0 and $48 \mathrm{~h}$ after PMSG, and 4 and $24 \mathrm{~h}$ after hCG. Tissues were sectioned at $4-5 \mu \mathrm{m}$, dewaxed and rehydrated. After quenching endogenous peroxidase activity in $1.5 \%$ hydrogen peroxide in methanol, tissue sections were blocked with $10 \%$ normal goat serum. The PPAR $\gamma$ antibody (E-8; 1:100 dilution) was applied overnight at $4{ }^{\circ} \mathrm{C}$. After rinsing, sections were incubated with a biotinylated secondary antibody (Amersham) and subsequently treated with a peroxidase/streptavidin conjugate (Vector Laboratories, Burlingame, CA, USA). The immunocomplex was detected by incubating the tissue sections with a diaminobenzidine solution (Zymed Laboratories, San Francisco, CA, USA). Normal goat serum was used in place of the anti-PPAR $\gamma$ antibody as a control. At least nine tissue sections from each of 3-4 animals/time point were analyzed.

\section{Immunoprecipitation and immunoblot analysis of PPAR $\gamma$}

Protein corresponding to PPAR $\gamma$ was immunoprecipitated from frozen rat ovarian tissue $(n=3-4$ /time point). Ovaries were homogenized in RIPA buffer $(1 \times$ phosphate buffered saline (PBS), 1\% NP-40, 0.5\% sodium deoxycho- 
late and $0.1 \%$ sodium dodecyl sulfate (SDS)) containing phenylmethylsulfonyl fluoride $(100 \mu \mathrm{l} / \mathrm{ml})$ and sodium orthovanadate $(1 \mathrm{mM})$. The homogenate was centrifuged, and $50 \mu \mathrm{l} / \mathrm{ml}$ protein A agarose (Repligen, Waltham, MA, USA) were added to the supernatant. After incubation and subsequent centrifugation, the supernatant was collected and $2 \mu \mathrm{g} / \mathrm{ml}$ anti-PPAR $\gamma$ antibody $(\mathrm{H}-100)$ was added and incubated. A volume of $50 \mu$ l protein A was added to the solution, and, after incubation, the solution was centrifuged. The supernatant was discarded and the pellet washed with RIPA buffer. The resultant pellet was resuspended in $40 \mu \mathrm{l}$ SDS buffer $(0.019 \mathrm{M}$ Tris $-\mathrm{HCl}, 0.186 \mathrm{M}$ glycine and $0.05 \%$ SDS).

To determine the phosphorylation status of PPAR $\gamma$, equal amounts of immunoprecipitate from ovarian tissue samples collected 0 and $48 \mathrm{~h}$ after PMSG, and 4 and $24 \mathrm{~h}$ after hCG were loaded onto a $10 \%$ polyacrylamide gel, separated by electrophoresis and transferred to a nitrocellulose membrane (Amersham). Membranes were blocked with 5\% milk and incubated with an antiphosphoserine antibody (MPM-2; 1:500 dilution). After washing, membranes were treated with a horseradish peroxidase-labeled secondary antibody (1:1000 dilution), and the immunocomplex was visualized with an enhanced chemiluminescence (ECL) kit (Amersham). Membranes were stripped and subsequently processed for immunodetection of PPAR $\gamma(E-8)$ to verify immunoprecipitation. Membranes were exposed to Kodak X-OMAT autoradiography film from $15 \mathrm{~s}$ to $5 \mathrm{~min}$ to ensure linearity of the signal. Films were scanned, and densitometry of the bands was conducted with AlphaEase 4.0 (Alpha Innotech, San Leandro, CA, USA).

\section{Cell culture}

Granulosa cells were cultured as previously described (Komar et al. 2001) with the following modifications. To investigate the role of PKA in the LH-mediated decline in mRNA for PPAR $\gamma$, granulosa cells were cultured with $\mathrm{LH}$ $(100 \mathrm{ng} / \mathrm{ml})$ in the presence and absence of H89 (10 or $30 \mu \mathrm{M})$, an inhibitor of PKA. LH and H89 were added to the cells at the time of plating. Cells were collected after 24-h culture and lysed with lysis buffer (Ambion, Austin, TX, USA). Cellular lysate was stored at $-70^{\circ} \mathrm{C}$ until analyzed by a direct lysate RNase protection assay. Progesterone was measured in conditioned media by RIA (Diagnostic Products, Los Angeles, CA, USA) (Komar et al. 2001). Treatment with $\mathrm{H} 89$ resulted in approximately $24 \%$ and $72 \%$ decreases in basal and LH-stimulated progesterone production respectively.

Cells were also treated with cycloheximide to determine the role of protein synthesis in the LH-stimulated decrease in mRNA for PPAR $\gamma$. Fetal calf serum (5\%) was used in the culture media in place of BSA. Cycloheximide $(10 \mu \mathrm{g} / \mathrm{ml})$ was added to cells at the time of plating, and LH $(100 \mathrm{ng} / \mathrm{ml})$ was administered to the cells 30 min later.
After 5-h culture, cells were collected and processed as described above.

\section{Quantification of mRNA for PPAR $\gamma$}

Plasmids containing cDNAs for PPARy (generously provided by Dr Walter Wahli, Université de Lausanne, Lausanne, Switzerland) and the ribosomal protein L32 (a gift from Dr O-K Park-Sarge, University of Kentucky, Lexington, KY, USA) were linearized with EcoRI. Antisense riboprobes were transcribed with Ambion's Maxiscript kit and $\alpha^{32} \mathrm{P}-\mathrm{UTP}$. Lysate ribonuclease protection assays (RPA) were carried out as described previously (Jo et al. 2002). Briefly, granulosa cell lysates were hybridized overnight with excess radiolabeled antisense riboprobes for PPAR $\gamma$ and L32. Protected fragments were analyzed by PAGE. Relative levels of mRNA for PPAR $\gamma$ and L32 were quantified with a phosphor imager (Molecular Dynamics, Sunnyvale, CA, USA). The band intensity of mRNA for PPARy was normalized to the corresponding band for L32 per sample.

\section{Statistical analysis}

Differences in levels of mRNA and protein corresponding to PPAR $\gamma$, and the amount of phosphorylated PPAR $\gamma$ in ovarian tissues were analyzed by ANOVA. Post-hoc comparisons were made with Tukey's HsD test. $P<0.05$ denoted significant differences.

\section{Results}

Previously, we reported that mRNA for PPAR $\gamma$ was localized primarily to granulosa cells of developing follicles, and that administration of hCG to PMSG-primed rats resulted in a significant decrease in levels of mRNA for PPAR $\gamma$ within $4 \mathrm{~h}$ (Komar et al. 2001). In the current study, protein corresponding to PPAR $\gamma$ was analyzed in ovarian tissue collected at defined times before and after the $\mathrm{LH}$ surge to determine whether the gonadotropin surge modified its expression and/or functional status.

PPAR $y$ was immunolocalized in ovarian tissue collected from immature rats 0 and $48 \mathrm{~h}$ after PMSG, and 4 and $24 \mathrm{~h}$ after hCG. PPAR $\gamma$ was expressed almost exclusively in granulosa cells of developing follicles, and was immunolocalized to the nucleus (Fig. 1). Expression of PPARy was relatively high in granulosa cells during follicular development (0 and $48 \mathrm{~h}$ after PMSG) (Fig. 1A and B). However, by $4 \mathrm{~h}$ after hCG, granulosa cells in some follicles lost expression of PPAR $\gamma$, while PPAR $\gamma$ expression remained high in other follicles (Fig. 1C). Interestingly, after the gonadotropin surge, the expression of PPAR $\gamma$ within a follicle appeared to decline in a progressive manner. PPAR $\gamma$ was highly expressed in some granulosa cells, but absent from others within the same follicle (indicated by arrows in Fig. 1C). The cumulus granulosa cells appeared to retain expression of PPAR $\gamma$ longer than mural 


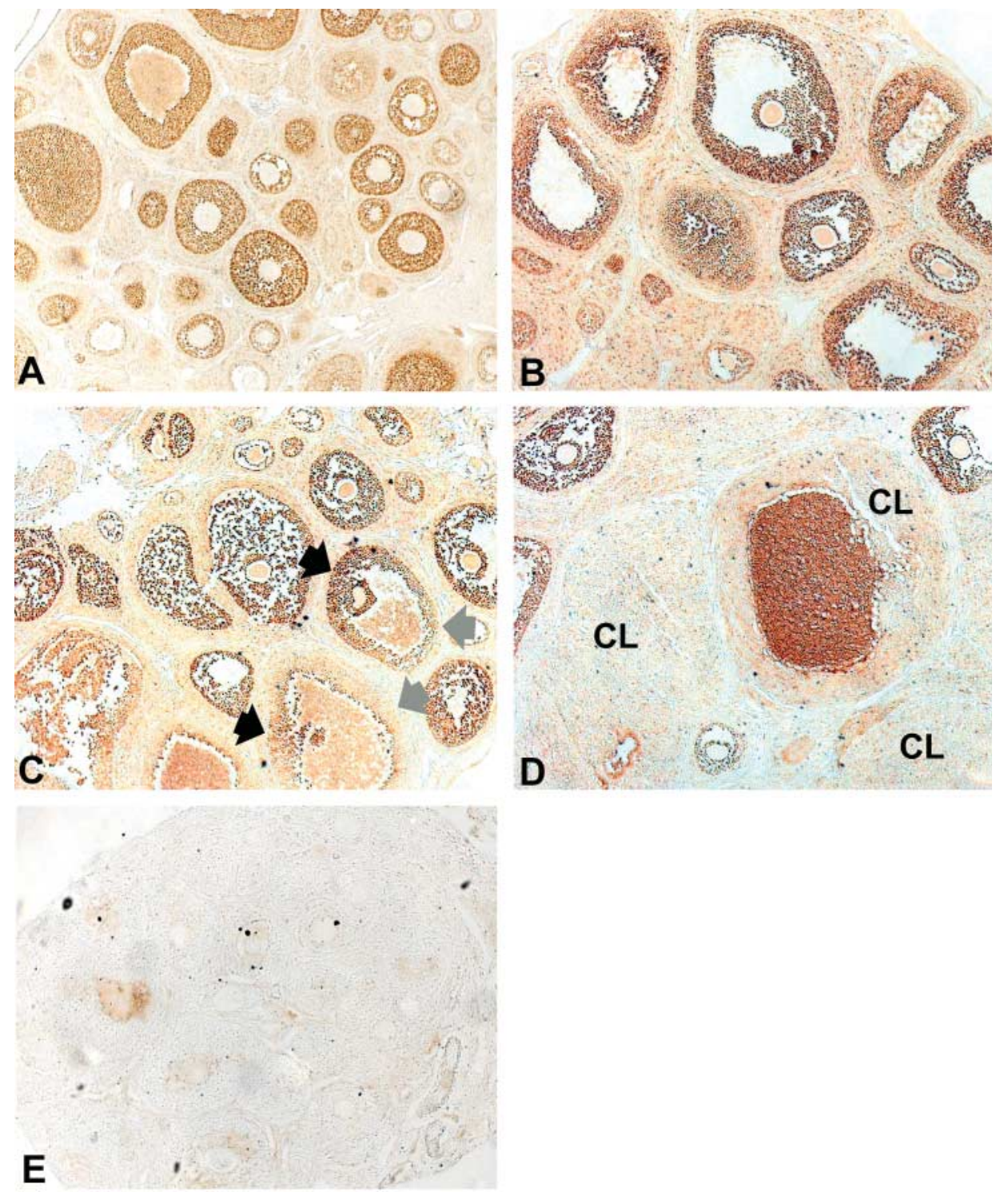

Figure 1 Immunolocalization of PPAR $\gamma$ in ovarian tissue sections collected from rats 0 (A, E) and 48 (B) h after PMSG, and 4 (C) and 24 (D) $h$ after hCG ( $n=3-4$ animals/time point). Tissue sections $(4-5(\mathrm{~m})$ were processed as described in Materials and Methods. Protein corresponding to PPAR $\gamma$ was identified by the brown reaction product. The tissue section pictured in (E) was treated with normal goat serum in place of the anti-PPAR $\gamma$ antibody. Arrows indicate granulosa cells expressing high levels of PPAR $\gamma$ (black) versus those that no longer express PPAR $\gamma$ (gray) within the same follicle. $\mathrm{CL}$ : corpus luteum. $\times 100$.

granulosa cells (Fig. 1C). By $24 \mathrm{~h}$ after hCG, expression of PPAR $\gamma$ in luteal tissue was very low (Figs 1D and 2A). Cells within the newly forming luteal tissue did express PPAR $\gamma$, albeit at a much lower level than what was observed in follicular cells (Fig. 2A).

Interestingly, in tissue collected from one animal $48 \mathrm{~h}$ after PMSG, the theca externa of a few follicles expressed PPAR $\gamma$ at a high level in a relatively uniform pattern (data not shown). Aside from certain follicles in this one animal, the expression of PPAR $y$ in the theca externa of other follicles in this animal, and in the other animals studied, was inconsistent and nonuniform (Fig. 1).
As mentioned above, the phosphorylation status of PPAR $\gamma$ can influence its activity. To determine whether the LH surge influences the activity of PPAR $\gamma$ by modifying the phosphorylation status of this transcription factor, PPAR $\gamma$ was immunoprecipitated from ovarian tissue collected during the periovulatory period. The phosphorylation status of PPAR $\gamma$ was determined both before and after the gonadotropin surge, and was expressed as a ratio of the amount of total PPARy in the sample. Levels of phosphorylated PPAR $\gamma$ tended to decrease $0-48 \mathrm{~h}$ after PMSG (reduced by $25 \% ; P>0.05$ ), and then remained steady throughout the remainder of the periovulatory period (data not shown). 


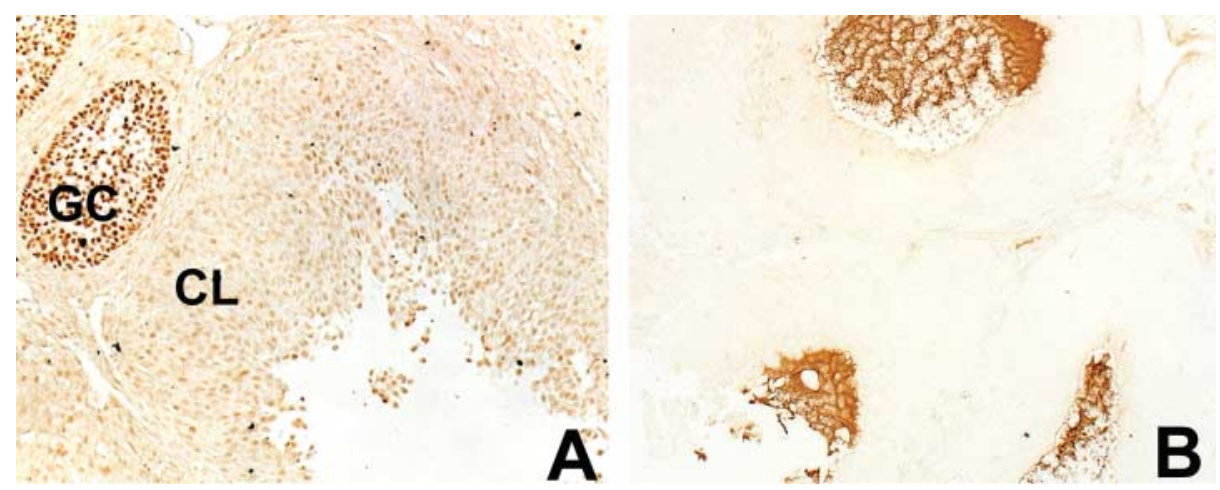

Figure 2 Immunolocalization of PPAR $y$ in rat ovarian tissue. Tissues were collected and processed as described in Materials and Methods. Protein corresponding to PPAR $y$ is identified by the brown reaction product. (A) Tissue section from an ovary collected $24 \mathrm{~h}$ after hCG. GC: granulosa cells; CL: corpus luteum. $\times 200$. (B) Tissue section from the same ovary depicted in $(A)$ incubated with normal goat serum in place of the anti-PPAR $y$ antibody. $\times 100$.

The LH surge sets in motion a cascade of events that culminates in ovulation and luteinization. To begin investigating the second messenger systems involved in the LHmediated decline in the expression of PPAR $\gamma$ in follicular cells, granulosa cells were treated with $\mathrm{LH}$ in conjunction with H89, an inhibitor of PKA. As seen in Fig. 3, H89 had no effect on the basal expression of mRNA for PPAR $\gamma$. However, administration of $\mathrm{LH}$ to the cultured cells reduced levels of mRNA for PPAR $\gamma$ by $54 \%$ compared with controls $(P<0.05)$ (Fig. 3). This reduction in mRNA for PPAR $\gamma$ in response to LH was not affected by cotreating the cells with H89 (Fig. 3B).

A

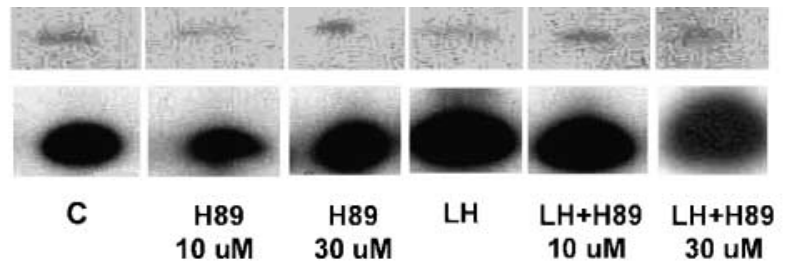

B

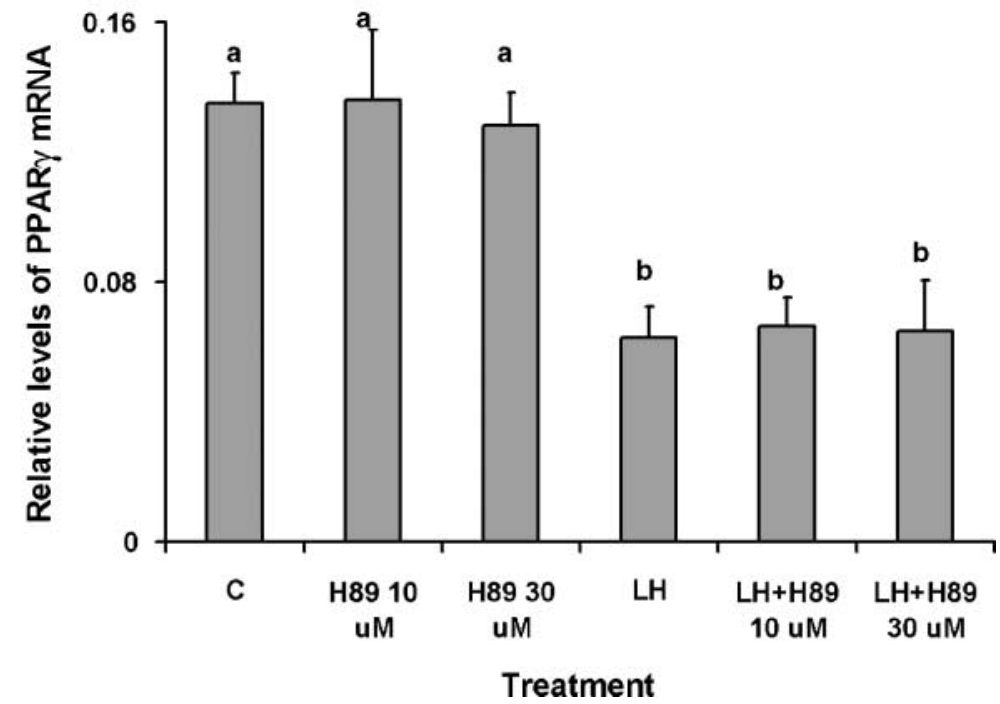

The role of protein synthesis in the LH-stimulated reduction in PPAR $y$ was also investigated by treating granulosa cells in vitro with cycloheximide. As seen in the previous experiment, treating the cells with $\mathrm{LH}$ caused a significant decrease in levels of mRNA for PPAR $\gamma$ $(P<0.05)$ (Fig. 4). When the cells were treated with both $\mathrm{LH}$ and cyclohexamide, the levels of mRNA for PPAR $\gamma$ were not different from those in control cells. Interestingly, granulosa cells treated with cyclohexamide alone had $30 \%$ more mRNA for PPAR $\gamma$ than did controls $(P<0.05)$ (Fig. 4B).
Figure 3 Levels of mRNA for PPARy in granulosa cells collected $48 \mathrm{~h}$ after PMSG and cultured with vehicle (control), LH (100 ng/ml) and/or H89 (10 or $30 \mu \mathrm{M}$; $n=4$ independent experiments). (A) Representative autoradiograph of direct lysate RNase protection assay demonstrating the protected fragments of mRNA corresponding to PPAR $y$ and the ribosomal protein L32. (B) Relative levels of mRNA for PPAR $\gamma$ after correcting for the amount of L32 in each sample. Data are expressed as means \pm S.E.M. Bars with no common superscripts are significantly different $(P<0.05)$. C: control. 
A

C

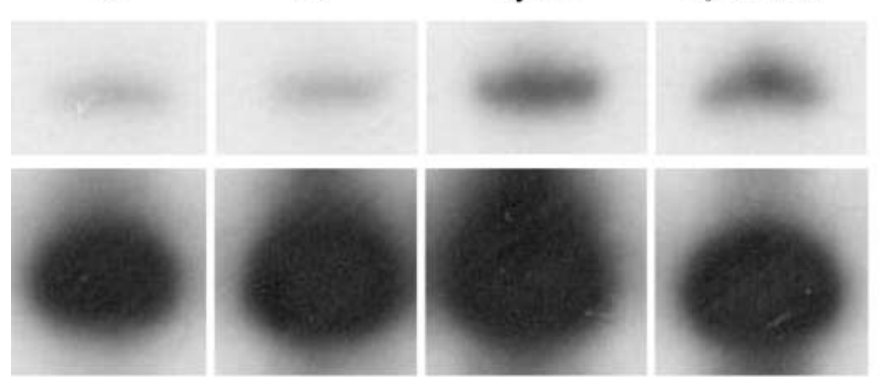

PPAR

L32

\section{B}

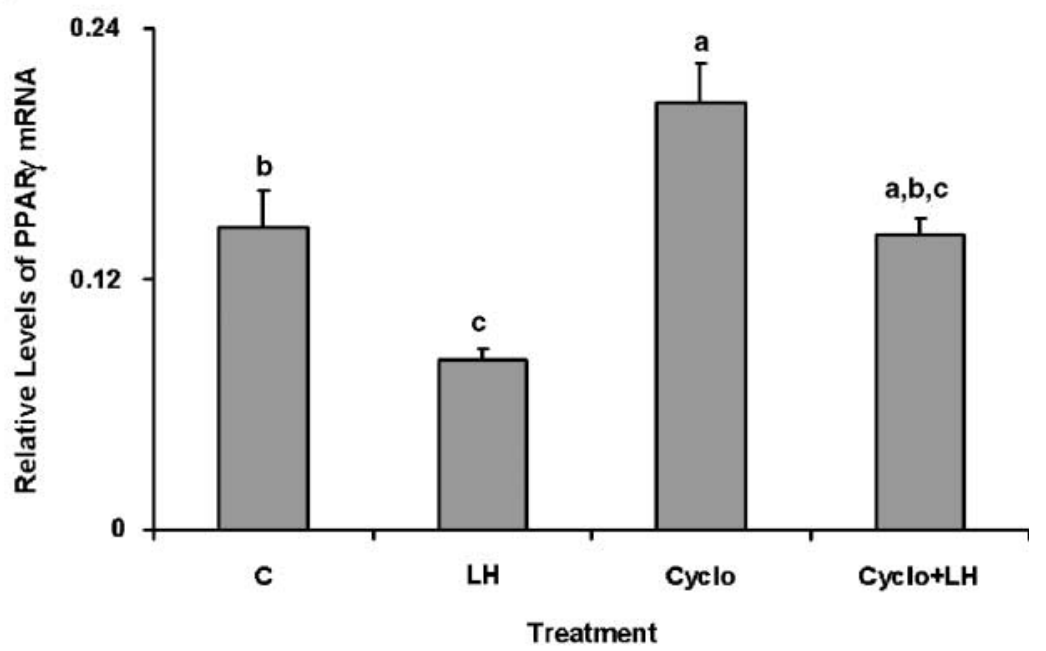

Figure 4 Levels of mRNA for PPARy in granulosa cells collected $48 \mathrm{~h}$ after PMSG and cultured with vehicle (control), LH (100 ng/ml) and/or cycloheximide $(10 \mu \mathrm{g} / \mathrm{ml} ; n=4-5$ independent experiments). (A) Autoradiograph of direct lysate RNase protection assay demonstrating the protected fragments of mRNA corresponding to PPAR $\gamma$ and the ribosomal protein L32. (B) Relative levels of mRNA for PPARy after correcting for the amount of L32 in each sample. Data are expressed as means \pm S.E.M. Bars with no common superscripts are significantly different $(P<0.05)$. C: control; Cyclo: cycloheximide.

\section{Discussion}

Data from various studies suggest that PPAR $\gamma$ plays a critical role in normal ovarian function. Using cre/loxP technology, Cui et al. (2002) disrupted the expression of PPAR $\gamma$ in granulosa cells, as well as B and T cells, and the mammary gland. One-third of these transgenic females were infertile, and the remaining two-thirds suffered from subfertility (Cui et al. 2002). The authors hypothesized that the fertility problems may have been caused by disruption of PPAR $y$ in the ovary, resulting in insufficient ovarian function to support implantation. In addition, studies by Froment et al. (2003) and Swan and Chaffin (2004) have shown that endogenous PPARy is functional in granulosa cells. In these studies, granulosa cells were transiently transfected with reporter constructs whose expression was driven by peroxisome proliferator-activated receptor response elements. Both in the absence and presence of agonists for PPAR $\gamma$, there was an increase in reporter activity (Froment et al. 2003, Swan \& Chaffin 2004), indicating that PPAR $\gamma$ is functional in granulosa cells and that endogenous ligand is also present within these cells (Swan \& Chaffin 2004).
Although PPAR $y$ has been identified in ovarian cells from various species, there is a paucity of information regarding how this transcription factor is regulated in the ovary, and what genes it targets in ovarian cells. We reported previously that $\mathrm{LH}$ regulates the expression of mRNA for PPARy in granulosa cells of developing follicles (Komar et al. 2001). In the current study, we show that the expression of protein corresponding to PPAR $\gamma$ parallels that of its mRNA. Taken together, these findings indicate that levels of both mRNA and protein corresponding to this transcription factor are tightly regulated in the ovary by $\mathrm{LH}$.

Further evidence supporting tight regulation of PPAR $\gamma$ in the ovary comes from the observed increase in basal levels of mRNA for PPAR $\gamma$ in granulosa cells treated with cycloheximide. Blocking protein synthesis led to significant accumulation of mRNA for PPAR $\gamma$. This finding shows that there is rapid turnover of mRNA for PPAR $\gamma$ in granulosa cells.

The high level of PPAR $y$ in developing follicles, both mRNA (Komar et al. 2001) and protein (current study), implies that this transcription factor is important in granulosa cell development and function. Since these processes depend on sequential and temporal patterns of gene expression, regulation of transcription factors would be 
one way to ensure that gene expression is tightly controlled. The current study demonstrates that $\mathrm{LH}$ decreases the expression of PPAR $\gamma$, but does not affect its phosphorylation status. Therefore, the activity of PPAR $\gamma$ in ovarian cells may be regulated moreso by controlling its expression, or by modifications other than phosphorylation.

LH can stimulate various second-messenger systems, including PKA and phospholipase C (Davis et al. 1986). The current study shows that the decline in PPARy is not mediated by the activity of PKA. High doses of LH, such as those attained during the $\mathrm{LH}$ surge, are associated with the activation of phospholipase $\mathrm{C}$ as well as PKA (Morris \& Richards 1993, Flores et al. 1998, and references therein). Therefore, the effect of $\mathrm{LH}$ on the expression of PPAR $\gamma$ may be mediated by activation of phospholipase C. Tyrosine kinases are also activated by LH (Davis 1994) and may be involved in regulating expression of PPAR $\gamma$. Studies are currently underway in our laboratory to determine the intracellular signaling mechanisms behind the $\mathrm{LH}$-induced decline in expression of PPAR $\gamma$.

The observed progression in the decline of PPAR $y$ in periovulatory granulosa cells, mural cells losing expression before the cumulus cells, is most likely the result of a direct effect of $\mathrm{LH}$. Because cumulus cells lack LH receptors (Peng et al. 1991), they do not respond directly to changes initiated by the LH surge, but rather indirectly via factors produced by neighboring mural granulosa cells.

Some effects of the LH surge are mediated by the progesterone receptor (Lydon et al. 1995, Robker et al. 2000, Shao et al. 2003). However, it is unlikely that the progesterone receptor plays a role in the effect of $\mathrm{LH}$ on the expression of PPAR $\gamma$. Blocking activation of the progesterone receptor in cultured rat granulosa cells by treating them with ZK98299 did not affect the LH-mediated decline in PPAR $\gamma$ (unpublished data, M Jo and C Komar). In addition, there is an inverse relationship between the $\mathrm{LH}$-mediated decrease in PPAR $\gamma$, and increase in the progesterone receptor; PPAR $\gamma$ declines by $4 \mathrm{~h}$ after hCG (Komar et al. 2001, current study), whereas the progesterone receptor increases 3-6h after hCG (Park \& Mayo 1991, Shao et al. 2003).

The LH-mediated reduction in PPARy may be one mechanism by which the gonadotropin surge effects changes in gene transcription allowing for ovulation, and luteinization of follicular cells. The rapid decline in PPAR $y$ in response to the $\mathrm{LH}$ surge, and low level of expression in developing luteal cells, indicates that genes transcriptionally regulated by PPAR $\gamma$ are not important agents in, and in fact may interfere with, ovulation and luteinization. For example, the downregulation of aromatase and cyclin D2, and upregulation of COX-2 in response to the $\mathrm{LH}$ surge, is important for the follicular/luteal phase shift and ovulation (reviewed by Richards 1994, Richards et al. 1998). Interestingly, these genes have been shown to be regulated by PPAR $\gamma$ in nonovarian tissues and cells (Meade et al. 1999, Laurora et al. 2003, Fan et al. 2005).

In cultured granulosa cells from PMSG-primed immature rats (Lovekamp-Swan et al. 2003) and human granulosa-lutein cells ( $\mathrm{Mu}$ et al. 2000), activation of PPAR $\gamma$ reduced the expression of aromatase. The inhibitory effect of PPAR $y$ on aromatase expression is through disrupting the interaction of NF-kB with the aromatase promoter II (Fan et al. 2005). Within $6 \mathrm{~h}$ of the gonadotropin surge, there is a significant decline in the expression of aromatase in granulosa cells (Hickey et al. 1988). We reported previously that there was no correlation between the expression of mRNAs for PPAR $\gamma$ and aromatase in granulosa cells during folliculogenesis or the periovulatory period (Komar \& Curry 2003). These observations, taken together with the fact that PPAR $\gamma$ is expressed in granulosa cells coincidently with estradiol production, suggest that this transcription factor may not inhibit aromatase in the ovary under normal, physiologic conditions.

Cyclin D2 has a similar profile of expression to PPAR $\gamma$. Like PPAR $\gamma$, cyclin D2 is expressed in granulosa cells of developing follicles and downregulated within $4 \mathrm{~h}$ of the LH surge, but only in follicles that responded to the gonadotropin surge (Robker \& Richards 1998). There are conflicting reports of how activation of PPAR $\gamma$ affects cyclin D2. In human leukemic cells, activation of PPARy resulted in a decline in mRNA and protein for cyclin D2 (Laurora et al. 2003). However, administration of troglitazone, a PPARy agonist, to cultured rat granulosa cells had no effect on cyclin D2 (Lovekamp-Swan \& Chaffin 2005). Froment et al. (2003) reported that treating granulosa cells from sheep with a PPAR $\gamma$ agonist decreased granulosa cell proliferation. More work investigating the role of PPAR $\gamma$ in granulosa cell-cycle progression is needed to address the apparent paradox of PPAR $\gamma$ inhibiting cell proliferation yet being expressed at a high level in developing granulosa cells.

Because the function of PPAR $\gamma$ varies depending on cell type and experimental parameters, it is difficult to define a role for PPAR $\gamma$ in the ovary by extrapolating from studies in other systems. The current study shows that the expression of PPARy is tightly regulated in the ovary, and that its expression appears to be the primary way this transcription factor is influenced by $\mathrm{LH}$. The pattern of expression of PPARy and its ability to affect a number of cellular functions suggest that its role in the ovary may be dictated by its relationship to other factors during the ovarian cycle. Because of its ability to influence many cellular functions, more work is needed to define the role of PPAR $y$ in the ovary in order to clarify how it is regulated and what genes it regulates during the ovarian cycle.

\section{Acknowledgements}

We thank Mary Jane Long and Joe Vislisel for their technical assistance; Dr S Lonergan and Dr E Huff-Lonergan for use of the AlphaEase analytic software; and Dr Misung Jo for 
critically reading the manuscript. This work was supported by National Institutes of Health grant HD40842. Preliminary findings were presented at the 37th Annual Meeting of the Society for the Study of Reproduction, Vancouver, Canada. The authors declare that there is no conflict of interest that would prejudice the impartiality of this scientific work.

\section{References}

Adams M, Reginato MJ, Shao D, Lazar MA \& Chatterjee VK 1997 Transcriptional activation by peroxisome proliferator-activated receptor $\gamma$ is inhibited by phosphorylation at a consensus mitogenactivated protein kinase site. Journal of Biological Chemistry $\mathbf{2 7 2}$ 5128-5132.

Barak Y, Nelson MC, Ong ES, Jones YZ, Ruiz-Lozano P, Chien KR, Koder A \& Evans RM 1999 PPAR $y$ is required for placental, cardiac, and adipose tissue development. Molecular Cell 4 585-595.

Berger J \& Moller DE 2002 The mechanisms of action of PPARs. Annual Review of Medicine 53 409-435.

Braissant O, Foufelle F, Scotto C \& Wahli W 1996 Differential expression of peroxisome proliferator-activated receptors (PPARs): tissue distribution of PPAR- $\alpha,-\beta$ and $-\gamma$ in the adult rat. Endocrinology $137354-366$.

Butts BD, Tran NL \& Briehl MM 2004 Identification of a functional peroxisome proliferator activated receptor response element in the $3^{\prime}$ untranslated region of the human bcl-2 gene. International Journal of Oncology 24 1305-1310.

Camp HS, Tafuri SR \& Leff T 1999 c-jun N-terminal kinase phosphorylates peroxisome proliferator-activated receptor- $\gamma 1$ and negatively regulates its transcriptional activity. Endocrinology $140392-397$.

Cui Y, Miyoshi K, Claudio E, Siebenlist UK, Gonzalez FJ, Flaws J, Wagner K-U \& Hennighausen L 2002 Loss of the peroxisome proliferation-activated receptor gamma (PPAR $\gamma$ ) does not affect mammary development and propensity for tumor formation but leads to reduced fertility. Journal of Biological Chemistry 277 $17830-17835$.

Davis JS 1994 Mechanisms of hormone action: luteinizing hormone receptors and second-messenger pathways. Current Opinion in Obstetrics and Gynecology 6 254-261.

Davis JS, Weakland LL, West LA \& Farese RV 1986 Luteinizing hormone stimulates the formation of inositol trisphosphate and cyclic $\mathrm{AMP}$ in rat granulosa cells. Evidence for phospholipase $\mathrm{C}$ generated second messengers in the action of luteinizing hormone. Biochemistry Journal 238 597-604.

Debril M-B, Renaud J-P, Fajas L \& Auwerx J 2001 The pleiotropic functions of peroxisome proliferator-activated receptor $\gamma$. Journal of Molecular Medicine 79 30-47.

Escher P \& Wahli W 2000 Peroxisome proliferator-activated receptors: insight into multiple cellular functions. Mutation Research 448 121-138.

Fan W, Yanase T, Morinaga H, Mu Y-M, Nomura M, Okabe T, Goto K, Harada N \& Nawata H 2005 Activation of peroxisome proliferator-activated receptor- $\gamma$ and retinoid $X$ receptor inhibits aromatase transcription via nuclear factor-кB. Endocrinology 146 85-92.

Flores JA, Aguirre C, Sharma OP \& Veldhuis JD 1998 Luteinizing hormone $(\mathrm{LH})$ stimulates both intracellular calcium ion $\left(\left[\mathrm{Ca}^{2+]} \mathrm{i}\right)\right.$ mobilization and transmembrane cation influx in single ovarian (granulosa) cells: recruitment as a cellular mechanism of LH$\left[\mathrm{Ca}^{2+}\right]_{\mathrm{i}}$ dose response. Endocrinology 139 3606-3612.

Floyd ZE \& Stephens JM 2002 Interferon- $\gamma$-mediated activation and ubiquitin-proteasome-dependent degradation of PPAR $\gamma$ in adipocytes. Journal of Biological Chemistry 277 4062-4068.

Froment P, Fabre S, Dupont J, Pisslet C, Chesneau D, Staels B \& Monget P 2003 Expression and functional role of peroxisome proliferator-activated receptor $\gamma$ in ovarian folliculogenesis in the sheep. Biology of Reproduction 69 1665-1674.
Hauser S, Adelmant G, Sarraf P, Wright HM, Mueller E \& Spiegelman BM 2000 Degradation of the peroxisome proliferator-activated receptor $\gamma$ is linked to ligand-dependent activation. Journal of Biological Chemistry 275 18527-18533.

Hickey GJ, Chen S, Besman M, Shively J, Hall P, Gaddy-Kurten D \& Richards JS 1988 Hormonal regulation, tissue distribution, and content of aromatase cytochrome P450 messenger ribonucleic acid and enzyme in rat ovarian follicles and corpora lutea: relationship to estradiol biosynthesis. Endocrinology 122 1426-1436.

Hsi LC, Wilson L, Nixon J \& Eling TE 2001 15-Lipoxygenase-1 metabolites down-regulate peroxisome proliferator-activated receptor ( via the MAPK signaling pathway. Journal of Biological Chemistry 246 34545-34552.

Hu E, Kim JB, Sarraf P \& Spiegelman BM 1996 Inhibition of adipogenesis through MAP kinase-mediated phosphorylation of PPAR $\gamma$. Science 274 2100-2103.

Jo M, Komar CM \& Fortune JE 2002 Gonadotropin surge induces two separate increases in expression of progesterone receptor in bovine periovulatory follicles. Biology of Reproduction 67 1981-1988.

Komar CM \& Curry TE Jr 2003 Inverse relationship between the expression of messenger ribonucleic acid for peroxisome proliferatoractivated receptor $\gamma$ and P450 side chain cleavage in the rat ovary. Biology of Reproduction 69 549-555.

Komar CM, Braissant O, Wahli W \& Curry TE Jr 2001 Expression and localization of PPARs in the rat ovary during follicular development and the periovulatory period. Endocrinology 142 4831-4838.

Lambe KG \& Tugwood JD 1996 A human peroxisome-proliferatoractivated receptor- $\gamma$ is activated by inducers of adipogenesis, including thiazolidinedione drugs. European Journal of Biochemistry $2391-7$.

Laurora S, Pizzimenti S, Briatore F, Fraioli A, Maggio M, Reffo P, Ferretti C, Dianzani U \& Barrera G 2003 Peroxisome proliferatoractivated receptor ligands affect growth-related gene expression in human leukemic cells. Journal of Pharmacology and Experimental Therapeutics 305 932-942.

Löhrke B, Viergutz T, Shahi SK, Pöhland R, Wollenhaupt K, Goldammer T, Walzel H \& Kanitz W 1998 Detection and functional characterisation of the transcription factor peroxisome proliferator-activated receptor $\gamma$ in lutein cells. Journal of Endocrinology 159 429-439.

Lovekamp-Swan T \& Chaffin CL 2005 The peroxisome proliferatoractivated receptor $\gamma$ ligand troglitazone induces apoptosis and p53 in rat granulosa cells. Molecular and Cellular Endocrinology 233 $15-24$.

Lovekamp-Swan T, Jetten AM \& Davis BJ 2003 Dual activation of PPAR $\alpha$ and PPAR $\gamma$ by mono-(2-ethylheyl) phthalate in rat ovarian granulosa cells. Molecular and Cellular Endocrinology 201 $133-141$.

Lydon JP, DeMayo FJ, Funk CR, Mani SK, Hughes AR, Montgomery CA Jr, Shyamala G, Conneely OM \& O'Malley BW 1995 Mice lacking progesterone receptor exhibit pleiotropic reproductive abnormalities. Genes and Development 9 2266-2278.

Mann JS, Kindy MS, Edwards DR \& Curry TE Jr 1991 Hormonal regulation of matrix metalloproteinase inhibitors in rat granulosa cells and ovaries. Endocrinology 128 1825-1832.

Marx N, Sukhova GK, Murphy C, Libby P \& Plutzky J 1998 Macrophages in human atheroma contain PPAR . American Journal of Pathology 153 17-23.

Marx N, Schönbeck U, Lazar MA, Libby P \& Plutzky J 1999 Peroxisome proliferator-activated receptor gamma activators inhibit gene expression and migration in human vascular smooth muscle cells. Circulation Research 83 1097-1103.

Meade E, McIntyre T, Zimmerman G \& Prescott S 1999 Peroxisome proliferators enhance cyclooxygenase-2 expression in epithelial cells. Journal of Biological Chemistry 274 8328-8334.

Mohan M, Malayer JR, Geisert RD \& Morgan GL 2002 Expression patterns of retinoid $X$ receptors, retinaldehyde dehydrogenase, 
and peroxisome proliferator activated receptor gamma in bovine preattachment embryos. Biology of Reproduction 66 692-700.

Morris JK \& Richards JS 1993 Hormone induction of luteinization and prostaglandin endoperoxide synthase-2 involves multiple cellular signaling pathways. Endocrinology 133 770-779.

Mu Y-M, Yanase T, Nishi Y, Waseda N, Oda T, Tanake A, Takayanagi R \& Nawata H 2000 Insulin sensitizer, troglitazone, directly inhibits aromatase activity in human ovarian granulosa cells. Biochemical and Biophysical Research Communications 271 710-713.

Ohshima T, Koga H \& Shimotohno K 2004 Transcriptional activity of peroxisome proliferator-activated receptor $\gamma$ is modulated by SUMO-1 modification. Journal of Biological Chemistry 279 $29551-29557$.

Park O-K \& Mayo KE 1991 Transient expression of progesterone receptor messenger RNA in ovarian granulosa cells after the preovulatory luteinizing hormone surge. Molecular Endocrinology $\mathbf{5}$ 967-978.

Peng X-R, Hsueh AJW, La Polt PS, Bjersing L \& Ny T 1991 Localization of luteinizing hormone receptor messenger ribonucleic acid expression in ovarian cell types during follicle development and ovulation. Endocrinology 129 3200-3207.

Reginato MJ, Krakow SL, Bailey ST \& Lazar MA 1998 Prostaglandins promote and block adipogenesis through opposing effects on peroxisome proliferator-activated receptor $\gamma$. Journal of Biological Chemistry 273 1855-1858.

Richards JS 1994 Hormonal control of gene expression in the ovary. Endocrine Reviews 15 725-751.

Richards JS, Russell DL, Robker RL, Dajee M \& Alliston TN 1998 Molecular mechanisms of ovulation and luteinization. Molecular and Cellular Endocrinology 145 47-54.

Robker RL \& Richards JS 1998 Hormone-induced proliferation and differentiation of granulosa cells: a coordinated balance of the cell

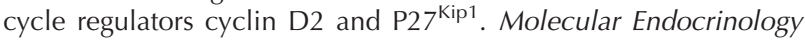
12 924-940.

Robker RL, Russell DL, Espey LL, Lydon JP, O'Malley BW \& Richards JS 2000 Progesterone-regulated genes in the ovulation process: ADAMTS-1 and cathepsin L proteases. PNAS 97 4689-4694.

Schoppe PD, Garmey JC \& Veldhuis JD 2002 Putative activation of the peroxisome proliferator-activated receptor $\gamma$ impairs androgen and enhances progesterone biosynthesis in primary cultures of porcine theca cells. Biology of Reproduction 66 190-198.

Shao R, Markström E, Friberg PA, Johansson M \& Billig H 2003 Expression of progesterone receptor (PF) A and $\mathrm{B}$ isoforms in mouse granulosa cells: stage-dependent PR-mediated regulation of apoptosis and cell proliferation. Biology of Reproduction $\mathbf{6 8}$ 914-921.

Shibuya A, Wada K, Nakajima A, Saeki M, Katayama K, Mayumi T, Kadowaki T, Niwa H \& Kamisaki Y 2002 Nitration of PPARy inhibits ligand-dependent translocation into the nucleus in a macrophage-like cell line, RAW 264. FEBS Letters 525 43-47.

Shu H, Wong B, Zhou G, Li Y, Berger J, Woods J, Wright S \& Cai TQ 2000 Activation of PPAR $\alpha$ or $\gamma$ reduces secretion of matrix metalloproteinase 9 but not interleukin 8 from human monocytic THP-1 cells. Biochemical and Biophysical Research Communications 267 345-349.

Sundvold H, Brzozowska A \& Lien S 1997 Characterisation of bovine peroxisome proliferator-activated receptors ${ }_{1}$ and $\gamma_{2}$ : genetic mapping and differential expression of the two isoforms. Biochemical and Biophysical Research Communications 239 857-861.

Swan T \& Chaffin C 2004 The PPAR $\gamma$ ligand troglitazone induces p53 and apoptosis in rat ovarian granulosa cells. Biology of Reproduction Special issue 139.

Theocharis S, Margeli A, Vielh P \& Kouraklis G 2004 Peroxisome proliferator-activated receptor- $\gamma$ ligands as cell-cycle modulators. Cancer Treatment Reviews 30 545-554.

Veldhuis JD, Zhang G \& Garmey JC 2002 Troglitazone, an insulinsensitizing thiazolidinedione, represses combined stimulation by $\mathrm{LH}$ and insulin of de novo androgen biosynthesis by thecal cells in vitro. Journal of Clinical Endocrinology and Metabolism 87 $1129-1133$

Yamakawa K, Hosoi M, Koyama H, Tanaka S, Fukumoto S, Morii H \& Nishizawa Y 2000 Peroxisome proliferator-activated receptor- $\gamma$ agonists increase vascular endothelial growth factor expression in human vascular smooth muscle cells. Biochemical and Biophysical Research Communications 271 571-574

Yee J, Kuncio GS, Bhandari B, Shihab FS \& Neilson EG 1997 Identification of promoter activity and differential expression of transcripts encoding the murine stromelysin-1 gene in renal cells. Kidney International 52 120-129.

Received 17 March 2005

First decision 24 May 2005

Revised manuscript received 29 August 2005

Accepted 30 September 2005 